\title{
AWARENESS ON PENSION PLANS-A STUDY OF INVESTORS’ IN BENGALURU CITY
}

\author{
-Pushpa B.V.* \\ *Research Scholar- Manipal Academy of Higher Education (MAHE), \\ Manipal 576104.
}

\begin{abstract}
Individuals make inconsistent, irrational financial decisions mainly due to disproportionate time preferences. Bias and procrastination prevail. Along with a default option, there is a need for a customized plan with individuals' socio-cultural and economic status. Low participation rates are mainly due to a lack of awareness of pension literacy and behavioral aspects. Individuals have failed to create a corpus to protect themselves for retirement as there is a lack of awareness to suitability of a plan to one's situation, failure to measure income adequacy at retirement, not able to identify the link between contributions made and pension drawdown, etc. Age and gender differences prevail strongly. Defined contribution plans are likely to dominate in global pension model in the years to come. Individuals are ready to own their risk but have little control and knowledge to cover themselves. Frequent timely and prompt advice or counseling from investment advisors will enable participants to understand the need, identify suitable options and schemes, and provide themselves with sustainable long-term savings. This should convert willingness to participate to real participation.

Keywords: Financial literacy, Pension knowledge, Defined contribution pension plans (DCP), irrational decision making, demographics.
\end{abstract}

\section{I.BACKGROUND OF THE STUDY}

India is the first Southeast Asian country to launch social security programs and initiated the Employee's State Insurance Act in 1948 and the Employee's State Provident Fund in 1952. The aim was to transfer benefits to workers on injury, death, loss of wage, maternity, health care, and regular income during post-retirement years. Recently, the government is bringing in several policy measures to make the pension scheme benefits reach the private sector and unorganized or informal sector employees/individuals. We have schemes such as EPF, the Indira Gandhi National Old Age Pension Scheme (IGNOAPS) catering to people at the base level of income/low-income formal sector workers, the
National Pension Scheme, NPS lite, and Swavalamban scheme (later replaced by Atal Pension Yojana (APY), Pradhan Mantri Vaya Vandana Yojana (PMVVY) and the Pradhan Mantri Shram Yogi Maandhan (PMSYM).

Like in most developed and emerging economies, including UK and Canada, in India, Defined Contribution Pension schemes are gaining popularity and are replacing the Defined Benefit Pension schemes. India introduced the National Pension Scheme as a common DC retirement saving avenue. Participation rates in NPS, though is still low, are gaining momentum.

Life cycle theory provides insights into consumption smoothing decisions of individuals. Literacy levels of individuals and financial knowledge correlate with one another strongly (Maarten Van Rooij 2011). Lack of financial literacy and attitude to saving more mainly towards retirement, procrastination, and inertia are major behavioural issues contributing to low savings rates (Rabin 1999). Maarten Van Rooij evidences a positive correlation between financial literacy and determinants of wealth, income, age, education, family composition, attitude towards savings, etc. The higher the financial knowledge, the lower the cost incurred and barriers in stock market investment. Lusardi, 2004, Clark et al., 2008 state that retirement seminars and counseling positively influence individuals in short-term/immediate behavior but do not support long-term and consistent positive participation behavior. Most individuals prefer to choose a pension plan with a default portfolio choice and withdrawal options. The main issues identified in the Indian context are the existence of the gender gap, unequal income distribution in the formal and the informal sector, disguised employment, and reasons behind the failure of insurance schemes. Adopting pension reforms to bring in the concept of Individual Retirement Accounts like in the UK, auto-enrolment, bringing in mandatory contribution practices will increase savings (Madhurima Das, 2016). Sampad Narayan Bhattacharya (2004) tries to examine the feasibility of defined benefit schemes in India. The paper suggests that the changing trend in the increase in 
longevity, the declining trend in interest rates, labor mobility, uncertainties in the market, etc., affect the stability of India's DB plans. In their paper, Sanyal, Ayanendu \& Singh, Charan (2013) propose a universal pension scheme mainly for the unorganized sector using simulation exercise. It attempts to estimate the fiscal cost of a universal pension scheme applicable to residents above 60 years of age. The plan, if implemented, will enhance the welfare of the working cohorts of India majority of whose future lies in uncertainty.

\section{THE PROBLEM STATEMENT}

Salaried employees/individuals depend on the amount they realize at retirement from mandatory EPF. Most of them fail to mobilize savings mainly because of increasing consumption expenses. Financial literacy is always associated with retirement planning. (Sharanjit Uppal 2016). Most of them have a very low-risk profile and depend on banks and financial institutions for savings even though they derive moderate returns. The pension amount one gets depends on the accumulation of corpus one makes during working years. Even though intermediaries come out with promotional programs to create more awareness amongst individuals and to emphasize the need to save towards retirement years in pension plans, the younger individuals, in particular, are not utilizing the available tools and information for planning towards pension savings. Long-term savings for post-retirement years, it appears, is not their priority at present. The present study, as such, aims to capture the demographic and behavioral aspects of awareness of individuals towards pension plans available in the market.

\section{OBJECTIVES}

1. To analyze the extent of awareness among investors towards features of Pension plans.

2. To analyze the impact of demographics on the level of awareness towards the features of pension plans.

\section{HYPOTHESES}

Ho1: There is no significant impact of demographics such as age, gender, income level, educational status, professional status, etc., on awareness towards features of pension plans.

$\mathbf{H}_{11}$ : There is a significant impact of age, gender, income level, educational status, professional status, etc., on awareness towards features of pension plans.

Ho2: There is no significant agreement about awareness towards features of pension plans in the individuals' minds.
PublishedOnline12April 2021

$\mathbf{H}_{12}$ : There is a significant agreement about awareness towards pension plan features in the individuals' minds.

\section{METHODOLOGY}

The study uses a cue sampling method to collect primary data from Investors in Bengaluru city. Sample respondents were selected from a random mix and approached for data. The respondents were briefed about the purpose and objective of the study. The respondent's data on demographics, income, consumption, savings, and investment were subject to verification. Those who are further willing to participate in the survey were given the structured questionnaire for data on awareness. The estimated number of households in Bengaluru city is 23.71 lakhs forms the population $(\mathrm{N})$ for the study, and the sample size comes around 120 households. A total sample of 134 households/ respondents were chosen, and data is collected in the form of the structured questionnaire by cue sampling method ${ }^{1}$. Likert's fivepoint scale is used to capture factor reflections. The data collected were subject to reliability analysis using Cronbach's alpha which is 0.984 , which means data is highly reliable and precise and can be subject to further statistical analysis. The KMO statistic is 0.894 , the chisquare value 1608.928 , and the p-value being 0.000 . An Eigenvalue of a minimum of 1.0 is kept for extraction of variables and factors. As many as three out of fifteen components are extracted with Eigen Values 11.226, which could explain $74.842 \%$ of the variance.

${ }^{1}$ Eichenbaum H,

Kuperstein M, Fagan A, Nagode J. Cue-sampling and goal-approach correlates of hippocampal unit activity in rats performing an odor-discrimination task.

The study considers these variables: The amount of contribution to building to a certain corpus, Frequency of contribution payable, Rate of historical returns disclosed by the fund, Maturity value of the policy, Mode of payment, Nomination facility, Bonus, if any, Contribution from the Employer or government, Loan facility available, Withdrawal norms and mode of withdrawal, the Investment Policy of the fund, Investment portfolio of contribution to Equity- Corporate bonds -Government securities, Provisions relating to annuitisation at retirement, Annuity plans of insurance companies to choose from, awareness towards tax benefit on the plan. Further analysis is by using Univariate and Bivariate tables and regression summary tables. 


\section{ANALYSIS OF DATA}

Table1: Respondent's profile

\begin{tabular}{|c|c|c|c|c|c|}
\hline Parameter & Mean & Median & Std. dev & $\begin{array}{l}\text { Standard } \\
\text { Error } \\
\text { Mean }\end{array}$ & Skewness \\
\hline Gender & 1.35 & 1.00 & 0.479 & 0.041 & 0.633 \\
\hline Age & 37.87 & 35.00 & 10.526 & 0.909 & 0.815 \\
\hline Marital status & 1.85 & 2.00 & 0.607 & 0.052 & 1.105 \\
\hline Working status of spouse & 1.59 & 2.00 & 0.494 & 0.043 & -0.368 \\
\hline Size of the family & 4.04 & 4.00 & 1.253 & 0.108 & 0.301 \\
\hline Earning members in the family & 1.95 & 2.00 & 0.887 & 0.077 & 0.562 \\
\hline Domicile status & 1.80 & 2.00 & 0.403 & 0.035 & -1.505 \\
\hline Education status & 4.13 & 4.00 & 1.007 & 0.088 & -1.335 \\
\hline Professional status & 2.69 & 2.00 & 1.340 & 0.116 & 0.744 \\
\hline Nature of job & 3.29 & 4.00 & 1.314 & 0.114 & -0.514 \\
\hline Years of experience & 12.20 & 10.00 & 9.928 & 0.858 & 3.731 \\
\hline Number of dependents & 2.16 & 2.00 & 1.032 & 0.089 & 0.304 \\
\hline Percentage of monthly salary you save & 2.33 & 2.00 & 1.219 & 0.105 & 0.686 \\
\hline Gross total income of the family & 58582.40 & 52500 & 31744.547 & 2742.31 & 1.231 \\
\hline Net income of the family & 53738.50 & 49000 & 30553.8 & 2639.45 & 1.270 \\
\hline
\end{tabular}

Source: Author's calculations

The composition of gender is $65 \%$ male and $35 \%$ female, and there were no outliers by gender. The mean age is 38 years. The standard deviation is 10.5 . There is a fair representation of people working in the sample against people working in the entire population. There are only five respondents out of 134 in the 60 plus age category (senior citizens category). $96.2 \%$ of the sample are earners, followed by $3.8 \%$ senior citizens. This sample represents earners who intend to save for a more extended time, given their income and consumption levels. $69.4 \%$ of respondents are married, $6.7 \%$ senior citizens, and the remaining $24.9 \%$ of respondents in the others' category. The working status of the spouse almost matches with the working status of the household. As such, there are no outliers concerning age, marital status, and working status.

The average size of the family is 4.04 , with a median size of 4.00. Given the sample standard deviation of 1.25 , the average or median size represents a typical urban size regarding metro city (Bengaluru city). Against an average of four members in the family, at least two of them are working. The education level of the sample is that of graduates and postgraduates $(83.6 \%)$. The sample consists of $61.9 \%$ who are working professionals, and others are on their own, barring 3.7\% who are retired and yet are still earning as scrap income (in addition to returns they earn every month). Given the sample size, the domicile status consists of $80 \%$ urban and $20 \%$ rural (including people who migrated from other cities and towns from other parts of India, covering all States of India). The nature of the job is mainly of professionals covering about $2 / 3^{\text {rd }}$ of the sample. Others belong to selfemployed, NPO, and other non-specified groups. The average years of experience is 12.2 years, with the median experience being ten years. The standard deviation of years of experience is 9.9 years. The median size of the organization in which the respondents are working is 140 . The median number of dependents is two per family. However, this does not apply to $6.1 \%$ of the sample who form the senior citizen's group.

Table2: Regression Analysis- Demographic Variables Vs. Retirement Readiness (Awareness towards Features of Pension Plan) Model Summary - Fixed Effects Model 
PublishedOnline12April 2021

\begin{tabular}{|c|c|c|c|c|c|c|c|}
\hline SI.No. & Demographic Variables & $\mathrm{R}$ & $\begin{array}{l}\mathrm{R} \\
\mathrm{SRQ}\end{array}$ & $\begin{array}{c}\text { ADJ } \\
\text { R } \\
\text { SQR }\end{array}$ & $\mathrm{F}$ & SIGN & $\begin{array}{l}\text { REMARKS } \\
\text { Accept or } \\
\text { reject } \mathrm{H}_{0}\end{array}$ \\
\hline 1 & Age in years & .504 & .254 & .151 & 2.453 & .004 & Accept $\mathrm{H}_{0}$ \\
\hline 2 & Marital status & .306 & .093 & .049 & 2.080 & .060 & Reject $\mathbf{H}_{0}$ \\
\hline 3 & Working status of spouse & .446 & .199 & .121 & 2.553 & .006 & Accept $\mathbf{H}_{0}$ \\
\hline 4 & Size of the family & .344 & .118 & .059 & 1.980 & .055 & Reject $\mathrm{H}_{0}$ \\
\hline 5 & Earning members in the family & .405 & .164 & .066 & 1.664 & .079 & Reject $\mathbf{H}_{0}$ \\
\hline 6 & Domicle status & .485 & .236 & .129 & 2.219 & .010 & Reject $\mathrm{H}_{0}$ \\
\hline 7 & Education status & .453 & .205 & .144 & 3.332 & .001 & Accept $\mathrm{H}_{0}$ \\
\hline 8 & Professional status & .431 & .185 & .081 & 1.773 & .052 & Reject $\mathbf{H}_{0}$ \\
\hline 9 & Nature of job & .091 & .008 & .001 & 1.106 & .295 & Reject $\mathbf{H}_{0}$ \\
\hline 10 & Years of experience & .547 & .299 & .201 & 3.066 & .000 & Accept $\mathrm{H}_{0}$ \\
\hline 11 & Size of the organisation & .544 & .296 & .206 & 3.276 & .000 & Accept $\mathbf{H}_{0}$ \\
\hline 12 & Number of dependents & .157 & .025 & .009 & 1.611 & .204 & Reject $\mathbf{H}_{0}$ \\
\hline 13 & $\begin{array}{l}\text { Percentage of monthly salary you } \\
\text { save }\end{array}$ & .499 & .249 & .160 & 2.799 & .002 & Accept $\mathrm{H}_{0}$ \\
\hline 14 & Gross Total Income of the family & .368 & .136 & .061 & 1.806 & .067 & Reject $\mathrm{H}_{0}$ \\
\hline 15 & Net Income of the family & .371 & .137 & .062 & 1.830 & .063 & Reject $\mathrm{H}_{0}$ \\
\hline
\end{tabular}

\section{Source: Author's calculations}

The awareness of investors in understanding pension plans' features is a vital variable considered for retirement readiness. The awareness level will enable them to buy a combination of pension plans or investment products to optimize their incomes. Table 2 above makes a detailed presentation of investor readiness in terms of awareness towards pension plans. Barring the nature of the job, all other demographic and nondemographic variables have strong correlations between awareness variables and demographics or nondemographics. The power of explanation adjusted for redundancy indicated by adjusted $\mathrm{R}$ square is reasonably more powerful for age, domicile status, education status, years of experience, and organization size. An analysis of R square and Adjusted R square suggests redundant explanatory variables in terms of non-significance influencing the dependent variable. Although step-wise regression was adopted, $\mathrm{F}$ values are more than one for all variables. All variables are statistically significant at varying levels, with alpha kept at 0.10 . i.e., the awareness to features of pension plans as identified by fifteen variables make an influence on age, marital status, working status, size of the family, number of earning members in the family, domicile, education, professional status, years of experience, and size of the organization. The two regressors that make the least significance are the nature of the job $(p=0.295)$ and the number of dependents $(p=0.204)$.

Table 3 Results of Regression - Demographic Variables Vs. Retirement Readiness (Awareness towards Features of Pension Plan)

\begin{tabular}{|c|c|c|c|c|c|c|c|c|c|c|c|c|c|c|c|c|c|}
\hline \multirow{2}{*}{$\begin{array}{l}\text { SL. } \\
\text { NO. }\end{array}$} & & & $\mathbf{R A}$ & $\mathbf{R A}$ & $\mathbf{R A}$ & $\mathbf{R A}$ & $\mathbf{R A}$ & $\mathbf{R A}$ & $\mathbf{R A}$ & $\mathbf{R A}$ & $\mathbf{R A}$ & $\mathbf{R A}$ & $\mathbf{R}$ & $\mathbf{R}$ & RA1 & $\mathbf{R A}$ & $\mathbf{R A}$ \\
\hline & & & 1 & 2 & 3 & 4 & 5 & 6 & 7 & 8 & 9 & 10 & $\begin{array}{l}\text { A1 } \\
1\end{array}$ & $\begin{array}{l}\mathbf{A 1} \\
\mathbf{2}\end{array}$ & 3 & 14 & 15 \\
\hline \multirow[t]{2}{*}{1} & $\begin{array}{l}\text { Age in } \\
\text { years }\end{array}$ & $\begin{array}{r}\mathrm{t}- \\
\text { valu } \\
\mathrm{e}\end{array}$ & .048 & .269 & $1.90^{-}$ & .586 & 1.02 & .607 & .222 & .766 & .884 & .512 & $\begin{array}{r}- \\
2.1 \\
9\end{array}$ & $\begin{array}{r}2.2 \\
4\end{array}$ & $\begin{array}{r}2.70 \\
8\end{array}$ & $\begin{array}{r}- \\
1.76 \\
7\end{array}$ & $\begin{array}{r}1.02 \\
4\end{array}$ \\
\hline & & $\begin{array}{r}\text { Sig } \\
\text { n. }\end{array}$ & .962 & .788 & .059 & .559 & .309 & .545 & .825 & .446 & .379 & .610 & $\begin{array}{r}.03 \\
1\end{array}$ & $\begin{array}{r}.02 \\
7\end{array}$ & .008 & .080 & .308 \\
\hline 2 & $\begin{array}{l}\text { Marital } \\
\text { status }\end{array}$ & $\begin{array}{r}\mathrm{t}- \\
\text { valu } \\
\mathrm{e}\end{array}$ & .299 & 1.52 & $\begin{array}{r}- \\
.235\end{array}$ & $\begin{array}{r}- \\
1.75\end{array}$ & 1.18 & $\begin{array}{r}- \\
1.77\end{array}$ & & & & & & & & & \\
\hline
\end{tabular}




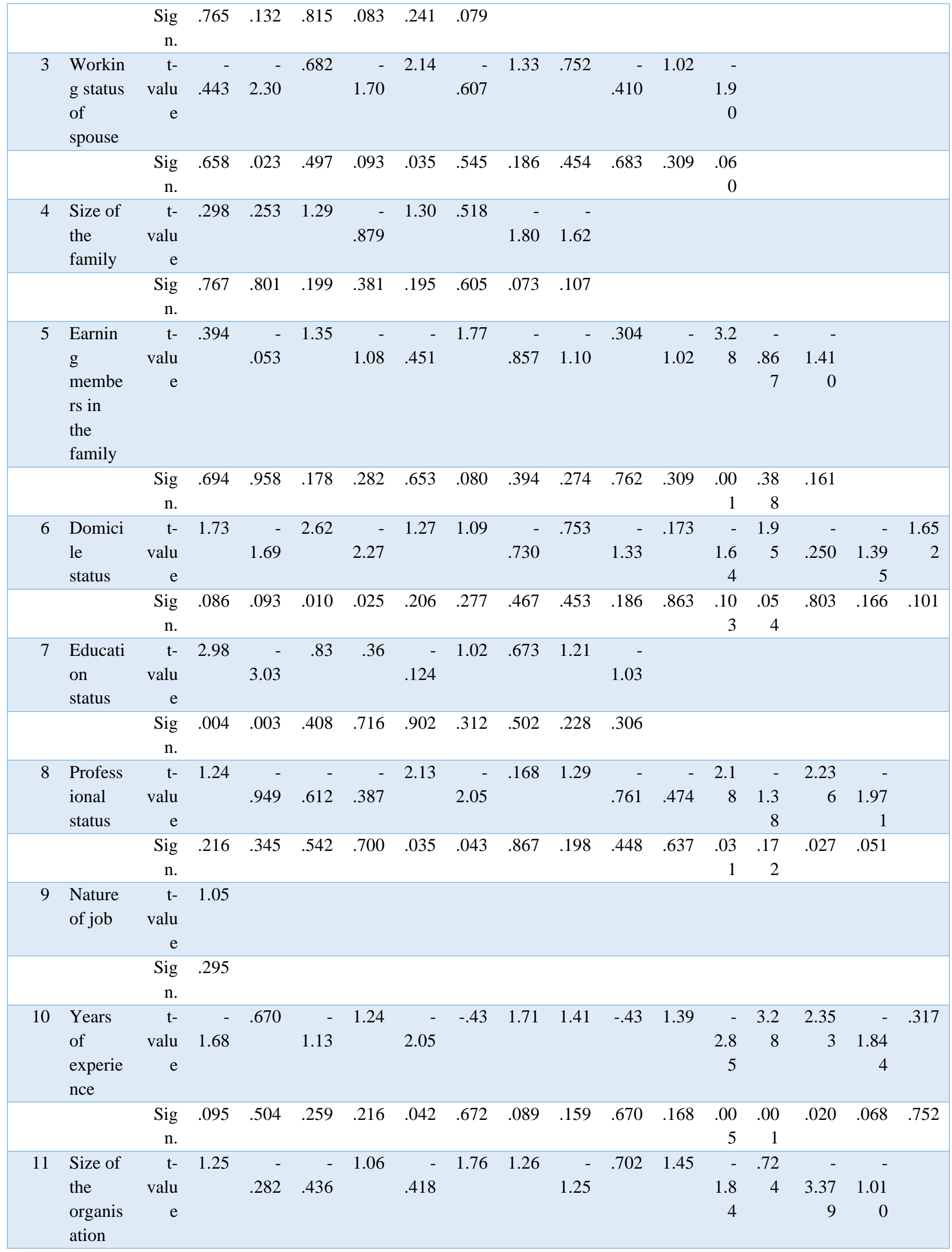




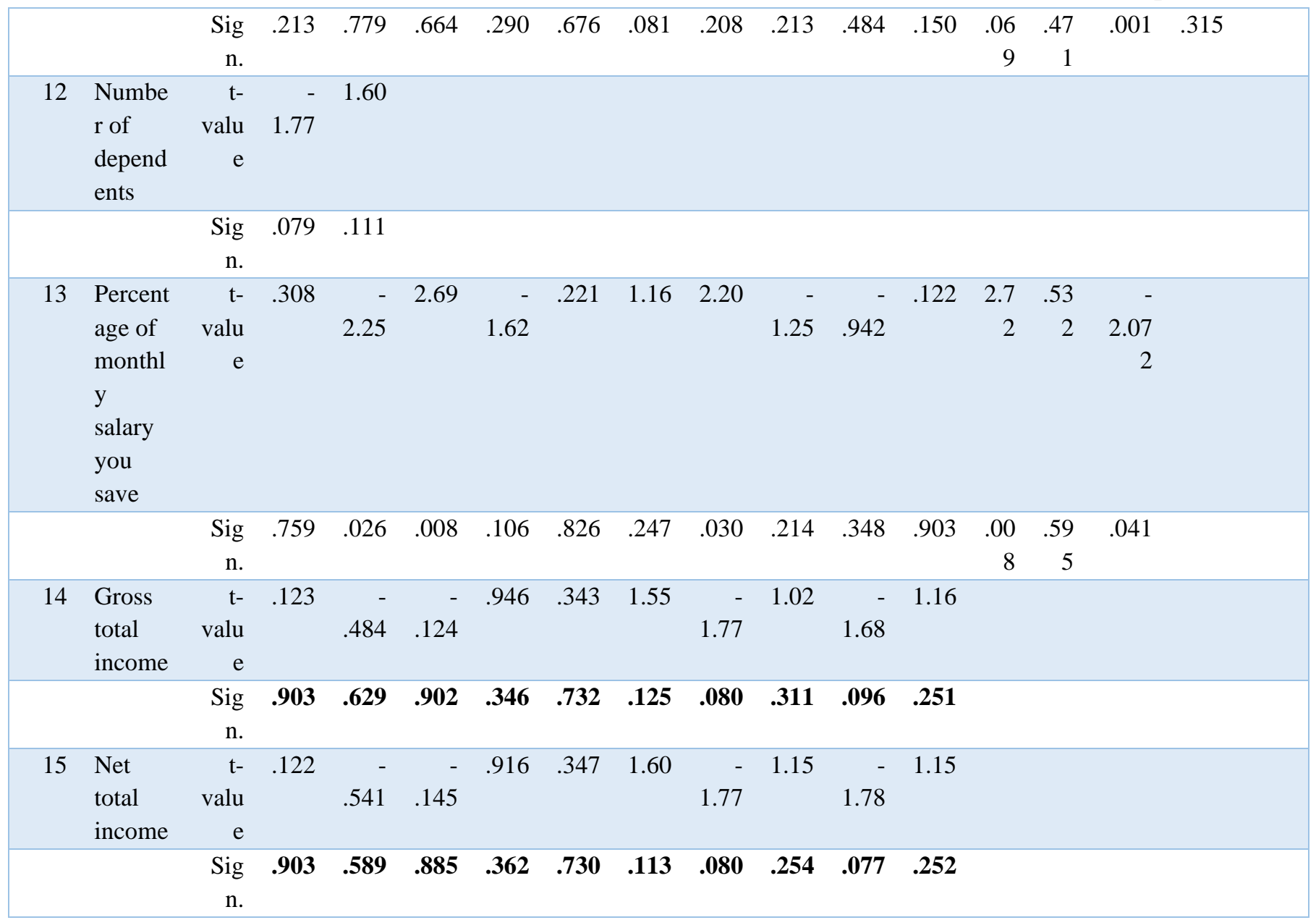

Source: Author's Calculations

Note: $1 . \mathrm{t}$ values and significance are presented

The table shows the results of regression with awareness as explanatory variables on regressands. Not all variables have a significant simultaneous influence on the chosen dependent variable. As age increases, historical returns ( $p=0.059)$ will be an added feature for decision-making. Further awareness towards investment policy $(\mathrm{p}=0.031)$, investment proportion in equity $(\mathrm{p}=0.027)$, annuitisation provision at retirement $(\mathrm{p}=0.008)$, and features of annuity plan make a greater influence with age. A marital status change will trigger maturity value $(\mathrm{p}=0.083)$ and nomination facility $(\mathrm{p}=0.079)$ as the main determinants. Frequency of contribution $(p=0.023)$, maturity value $(p=0.093)$, modes of payment $(p=0.035)$ and investment policy $(\mathrm{p}=0.060)$ will dictate working status. The higher the working status, the better will be a look at investment policies.

Bonus is a significant factor (0.073) as family size increases. Similarly, the nomination facility $(\mathrm{p}=0.080)$ and the sponsor's investment policy (0.001) will

\section{Significance value $=0.10$}

influence the number of earning members more than one in a family. Acquisition of status of domicile will be influenced by, size of contribution ( $p=0.086)$, frequency of return $(\mathrm{p}=0.093)$, historical returns $(\mathrm{p}=0.010)$, maturity value $(p=0.025)$, and investment contribution to equity $(p=0.054)$. Awareness towards investment contribution to equity and domicile status are strongly associated. The higher the education, the higher will be the size of contribution $(\mathrm{p}=0.004)$ and its frequency of contribution $(p=0.003)$. The more educated an investor is, the more he will look into allocation decisions. Professionals care for mode of payment $(\mathrm{p}=0.035)$, nomination facility $(\mathrm{p}=0.043)$, investment policy $(\mathrm{p}=$ $0.031)$, annuitisation provisions $(\mathrm{p}=0.027)$ and annuity plans of insurance companies available (0.051). The nature of the job is not influenced by any explanatory variable, including the size of the contribution. The fund sponsor and investment portfolio's investment policycontribution to equity and fixed income securities make 
cognizance as experience increases ( $\mathrm{p}$ values 0.095, 0.042 , and 0.089 respectively). Provision relating to annuitisation of at retirement ( 0.068), annuity plans available to choose from ( 0.020$)$ contribution to equity ( $0.001)$, the Investment policy of the sponsor ( 0.005), bonus (0.089), mode of payment of contribution (0.042) and size of contribution ( 0.095) matter as learning happens with experience. A more experienced person is a better investor. Can he/she wait to accumulate experience for decision making? Those relevant variables at a particular point in time will be considered appropriate, normal, and decisive. The larger the organisation, the more will be consideration for annuitisation policy $(\mathrm{p}=0.001)$, investment policy (0.069), and nomination benefits $(p=0.081)$. As the number of dependents increases, the size of the contribution of the investor will decrease significantly. The expansion in consumption will lead to a reduction in contribution size. As an investor's career will experience vicissitudinal changes, there will be more concern for annuitisation policy, policy options available, size of the bonus, and historical performance and payment frequency. Bonus and loan options are the main considerations with the increase in total gross income or total net income or both $(\mathrm{p}=0.080$ and 0.080 and 0.096 and 0.077).

\section{DISCUSSION AND KEY FINDINGS}

There is little or no awareness of the contribution to accumulate a corpus level (64.2\%). Investors, in general, are not averse to making a definite size of contribution provided factual information is made known to them under different plans. Only $10.4 \%$ claim to be aware of the frequency of return of a product. Nearly one out of four $(23.1 \%)$ of the respondents know the past trends in returns. One-third of investors are fully aware, partly aware, or not at all of the value of returns at maturity. As much as $41 \%$ of the investors are fully aware or aware, followed by $1 / 3$ rd $(32.8 \%)$ not aware. There is a high awareness level about the mode of payment. The investors are either conversant or ready to operate on any mode provided technical and operational knowledge is made available. Only one out of three $(32.1 \%)$ are aware or fully aware, one out of four partly aware, and as such, there is a need to educate customers on legal documentation under KYC. There is no clear knowledge about bonus and incentives, among other things. One out of four $(26.1 \%)$ of customers is fully aware of the employer's contribution, whereas $35.8 \%$ are not aware. Only one out of five $(26.9 \%)$ are fully aware of loan benefits on their plans. As much as $30.6 \%$ of the customers are aware or fully aware. $69.4 \%$ of them are either not aware or neutral of the withdrawal facility that comes with the pension plan. $21.6 \%$ of the investors are not aware of the organization's investment policy, and nearly $2 / 3^{\text {rd }}$ of the customers $(69.4 \%$ ) are not at all or partly aware. Accumulation of the corpus in the annuity market is little known to many customers $(69.1 \%$ and $73.8 \%$ ). At least nearly half of the investors are not aware of tax provisions. There is the least influence of awareness variables on the nature of the job $(p=0.295)$, the number of dependents in the family $(p=0.204)$. All other demographic variables are statistically significant. The general reflection is on age $(p=0.004)$, marital status ( $p=0.060)$, working status $(p=0.006)$, size of the family $(\mathrm{p}=0.055)$, number of earning members $(\mathrm{p}=$ $0.079)$, domicile status $(\mathrm{p}=0.010)$, education status $(\mathrm{p}=$ $0.001)$, professional status $(\mathrm{p}=0.052)$, years of experience $(p=0.000)$, size of the organisation $(p=$ $0.000)$, percentage of monthly salary you save $(\mathrm{p}=$ $0.002)$, gross total income $(\mathrm{p}=0.067)$, Net income ( $\mathrm{p}=$ 0.063 ) and insurance savings $) \mathrm{p}=0.038$ ). All these variables contribute to their level of awareness in terms of the significance of pension plan features.

\section{CONCLUSION AND IMPLICATIONS OF THE STUDY}

The study evidence that most people do not plan their retirement. There is a great need to bring awareness towards existing pension plans and their features and help individuals' decision-making towards long-term pension savings. Financial education programs need to be conducted more effectively and expanded for better coverage. It is imperative for salaried individuals in their earning years to know their financial requirements after retirement to maintain their standard of living. Of late, even youngsters are getting to understand creating a corpus, but planning to maintain the expected standard of living in non-working/earning years is as vital as life itself!

\section{REFERENCES}

1. Annamaria Lusardi and Olivia S. Mitchell (December 2005). Financial Literacy and Planning: Implications for Retirement Wellbeing. Working Paper, Michigan Retirement Research Center, University of Michigan. 
2. Camerer, C., S. Issacharoff, G. Loewenstein, T. O’Donoghue and M. Rabin (2003). Regulation for conservatives: Behavioral Economics and the Case for “Asymmetric Paternalism." University of Pennsylvania Law Review, 151 (1211), 1211-1254.

3. Chachad, Suyog and Singh, Komal (2018). Are You Making Yourself Retirement Ready - A Study of Salaried Individuals? International Journal of Management and Social Science Research Review, Vol1, Issue-43, January-2018, Available at SSRN: https://ssrn.com/abstract=3348864.

4. Clark, R., M. Morrill en S. Allen (2012). The role of financial literacy in determining retirement plans. Economic Inquiry, 50, 851-866.

5. Das, Madhurima (2016). Review of Pension Schemes in India. (June 4, 2016). Available at SSRN: https://ssrn.com/abstract=2796139 or http://dx.d oi.org/10.2139/ssrn.2796139

6. Dinesh Bansilal Shendkar (2016). Study of financial planning for retirement amongst individuals in the select age group of 25 years to 45 years in Pune city. Tilak Maharashtra Vidyapeeth. http://hdl.handle.net/10603/150714, Ph.D.

7. Eichenbaum H, Kuperstein M, Fagan A, Nagode J. Cue-sampling and goal-approach correlates of hippocampal unit activity in rats performing an odordiscrimination task. J Neurosci. 1987 Mar; 7(3):716-32. doi: 10.1523/JNEUROSCI.07-03-00716.1987.

PMID: 3559709; PMCID: PMC6569079.

8. Maarten van Rooij, Annamaria Lusardi and Rob Alessie (2011). Financial Literacy, Retirement Planning and Household wealth. Working paper No.313, August 2011, JEL classification: D91, D12, J26.

1. Michael Ntalianis \& Victoria Wise (2000). The Role of Financial Education in Retirement Planning. Australasian Accounting, Business and Finance Journal, Volume 5, Issue 2, Article 3, Pg 21-35. M.W. Hislop: Cue-Sampling strategies and the Role of Verbal Hypotheses in Concept Identification: Ph.D. thesis, Mc Master University, March 1970, pp-1-238.

9. Mohan. S. Kankanhalli, J. Wang, and R. Jain, "Experiential sampling in Multimedia Systems," IEEE Transactions on Multimedia, Vol. 8, No. 5, pp. 937-946, Oct. 2006.

10. Prof. Priya Vasagadekar (2014). A Research Paper on Investment Awareness among Indian Working with reference to Pune region."International Journal of Scientific \& Engineering Research", Volume 5, Issue 6, June-2014.
11. Sanyal, S. (2005). Demographics, Savings and Hyper-growth. Deutsche Bank Global Markets Research, July 5.

12. Sharanjit Uppal (2016). Financial literacy and retirement planning. Insights on Canadian Society, March 2016 - Statistics Canada, Catalogue no. 75-006$\mathrm{X}$. 